野菜料理情報にみる食材選択の多様性の検討

\author{
茂木美智子 \\ （東横学園女子短期大学）
}

\title{
Diversity of Food Choice as Observed in the Published Food Magazines
}

\author{
Michiko Moteki \\ Toyoko Gakuen Women's College, 8-9-18 Todoroki, Setagaya, Tokyo 158 \\ 厂158 東京都世田谷区等々力8-9-18
}

To estimate the diversity in food choice, 72pieces of magazine which were published 1976 to 1991 including 1,875 vegetable dish recipes in total were analyzed by analysis of bibliometrics.

The recipes were analyzed into foodstuff level and then discussed about diversification according to the sort of foodstuffs, the frequency of foodstuffs and the Diversity Index. The results were as follows;

1. The number of foodstuffs average 8.2 per one vegetable dish. This number has gradually decreased from 1979 to 1991 .

2. As regards the sort of foodstuffs "vegetable and its processed foods" in the classification is the most, and observed 104 kinds of vegetable per year in average.

3. As regards frequency, "various kinds of seasoning" in the classification is the most, and it became certain that these sorts of foodstuff are used more frequently than another foodstuffs in the vegetable dishes.

4. As regards Diversity Index, big changes have not taken place during these sixteen years except 1976 .

5. There is a high correlation between Diversity Index and frequency cumulative of several foodstuffs which are situated in the top rank in Cumulative Relative Frequency Distribution.

食材の選択に抢ける多様性の検討のため, 1976年から1991年に発行された, 食の専門雑誌から 採録した1875件の野菜料理を対象に，ビブリオメトリックスにより検討を行った。

野菜料理レシピは食材（食品）レベルで解析し, 食材種類, 出現頻度, 多様化度について検討 した．結果の概要は以下の通りである.

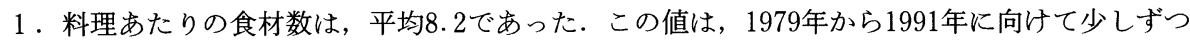
小さくなっていた.

2. 食材種類数として最も多かったのは, 野菜および加工品であり, 年間平均で104種類であった.

3. 採録頻度の最も高かったのは, 調味を目的として用いられた食材であり, 野菜料理において これらが最も多用されていることが明らかとなった。

4. 多様化度は, 1976年を除き観測年間大きな変化がみられなかった。

5. 多様化度と累積度数分布の上位品目の累積度の間に, 高い相関がみられた。 


\section{1. 緒 言}

食生活分析は，栄養素や金額といった定量の可能な因 子による分析から，食生活運営にかかわるさまざまな生 活要因，広くは料理や文化のよらなレベルでの接近へと 分析の拡大が必要な時期に達しているが，継続性のある 既往の行政統計類は高い信頼性をもちながらもその利用 にはかなりの制約が生じる，例えば，国民栄養調查1) 家 計調査年報 ${ }^{2)}$ などは既存の大きな分類項目で括られた結 果で示されるため, より詳細な, 例えば “その他品目” で括られてしまっている内容への接近といった試みには 原データを用いての再加工が不可能な場合が多い。

このよらな制約もあって，本報のよらに食材選択の結 果を調理のレベルで検討するよらな場合, 独自に設計し た調査から情報を得るほか, 新聞, 雑誌, 料理書, 給食 記録などに残されている料理や献立に関する情報（以下 料理情報と呼ぶ）をデータとして接近する試みが，要素 分析, 構造分析などの名称でこれまでにいくつか発表さ れている ${ }^{3)}$ ６)，本報では，このよらな試みに対し情報 学分野で用いられているビブリオメトリックス分析 ${ }^{7)}$ いら名称を用いて，野菜の選択利用の最終段階に位置す る野菜料理を対象に, 野菜料理に利用される食材の種類, 出現頻度などの基礎情報を得,さらにこれら食材の選択， 利用の多様性に関して, 多様化度指数を適用して分析的 に検討を行らことを目的とした。

多様性は，生態学においては質的なバラッキを表現す ると定義されて打り ${ }^{8)}$ 10)，多様であるということは， 系が複雑であり，外的要因に対する系の平衡度が高く， 安定性に富むといった概念を含さ. 食生活研究分野では, 鈴木 ${ }^{11)}$ が栄養素摂取に括ける食物構成の多様化に関し， また足立 ${ }^{12)}$ は，食生活を料理や食事のレベルで捉える 試みとして多様性を表現する指数を定義し検討を加えて いるが，汪かに多様性の実証的検討例は少ない，食生活 の多様化論が現在の食生活を描写している中にあって, 多様の意味を明らかにすることは, 現在必要な課題と考 えられる. 本報では, 食生活運営といら視点から家計内 調製を想定し，雑誌に記載された野菜料理情報を資料と して，選択された食材の多様性の実態を計る指標に G. W. Forster の多様化度指数 ${ }^{13)}$ を用いて検討を行ったの で報告する。

\section{2. 情報の加工方法と多様化度指数}

\section{（1）情報の採録と加工方法}

対象雑誌は継続性があり, 発行時の社会情勢を反映し,
食物に関してある程度の専門的な裏付けのあるものの中 から，ここでは女子栄養大学出版部発行「栄養と料理」 $1976 ， 1979 ， 1982 ， 1985 ， 1988 ， 1991$ 年分の各 1 月号〜 12 月号を対象とした。

採録した料理は, 同雑誌の編集方針として野菜料理に 分類されているもの，また，野菜料理に分類されていな いが野菜使用総重量が50\%を超えるもの, 豆料理, きの こ料理も含めた. 以上のいずれかに該当するものであっ ても, 行事食, 病人食など特別な目的に添って編集され ている料理は今回の分析対象から除外した。

インデクシングは既報14）15）に準じ，基礎統計処理を 行った．食品コードは四訂食品成分表に準じたが，調味 料やスパイス類ではかなりのコードを補足し，また調理 上その選択に意味があると考兄られたもの，例えば水， 出汁, 揚げ油, 炒め油などは独立品目として新たにコー ドを設けた。

\section{(2) 多様化度指数の計算}

多様化度指数（Diversity Index, 以下多様化度あるい はD.I と呼ぶ)については，G.W.Forsterによる次の ような定義を用い，計算を行った。

$$
\begin{aligned}
\text { D. } \mathrm{I} & =\frac{1}{\left(\frac{x_{1}}{X}\right)^{2}+\left(\frac{x^{2}}{X}\right)^{2}+\cdots+\left(\frac{x_{n}}{\mathrm{X}}\right)^{2}} \\
& =\frac{1}{\sum_{i=1}^{n}\left(\frac{x_{i}}{X}\right)^{2}}=\frac{X^{2}}{\sum_{i=1}^{n} x_{i}{ }^{2}}
\end{aligned}
$$

但し，構成項目が $1,2, \cdots \cdots, n$ 個であるとする. 構成項目の $i$ 番目の值を $x_{i}$ とする

$$
\mathrm{X}=x_{1}+x_{2}+\cdots \cdots x_{n}
$$

\section{3. 結果および考察}

\section{（1） 採録内容の概要}

採録料理件数は年間平均 313 件で，本雑誌にみられる 年間平均約 800 件の料理件数も含め，年次によるバラッ キが大きく経年変化に一定の傾向はみられなかった．

食材の種類数は各年とも平均 282 種類の食材が出現し たが，この数は年次による変動が大きく，一定の傾向は みられなかった. 食材の出現頻度は各年平均 2,557 度数 であったが，年次による変動が大きく，経年傾向はみら れなかった。

以上, 採録件数 ·食材の種類 - 頻度などに 16 年間の変 化を見いだせる傾向が検出できなかったので,料理件数・ 食材種類ごとの出現頻度から，1野菜料理を構成する食 材数を食材分類ごとの頻度数の比率で計算し，16年間の 


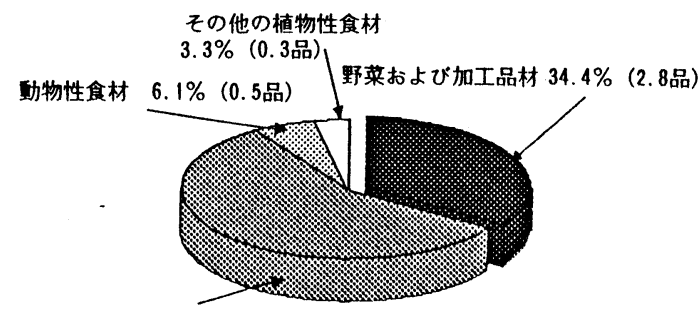

調味を目的とする食材 $56.2 \%$ (4.6品)

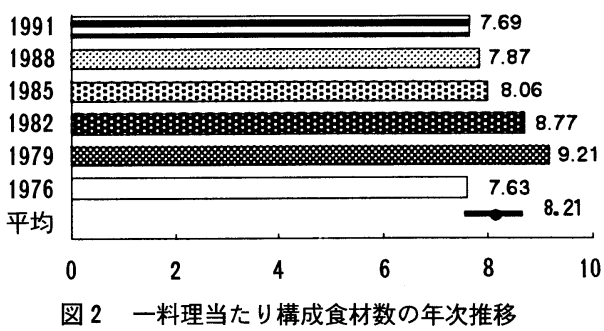

図 2 一料理当たり構成食材数の年次推移

図 1 野菜料理の構成

食材出現頻度合計を $100 \%$ （8.2品）とする

大分栔
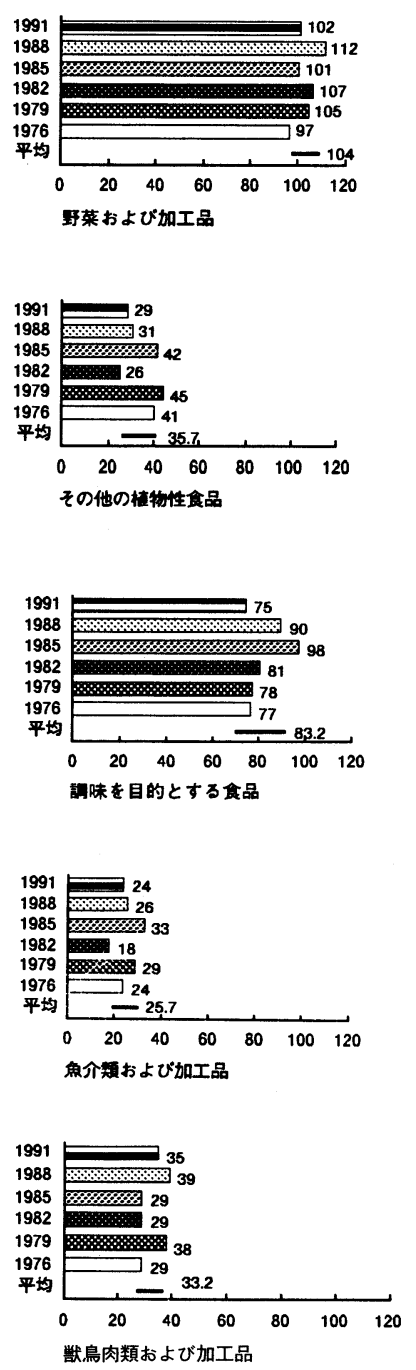

小分类
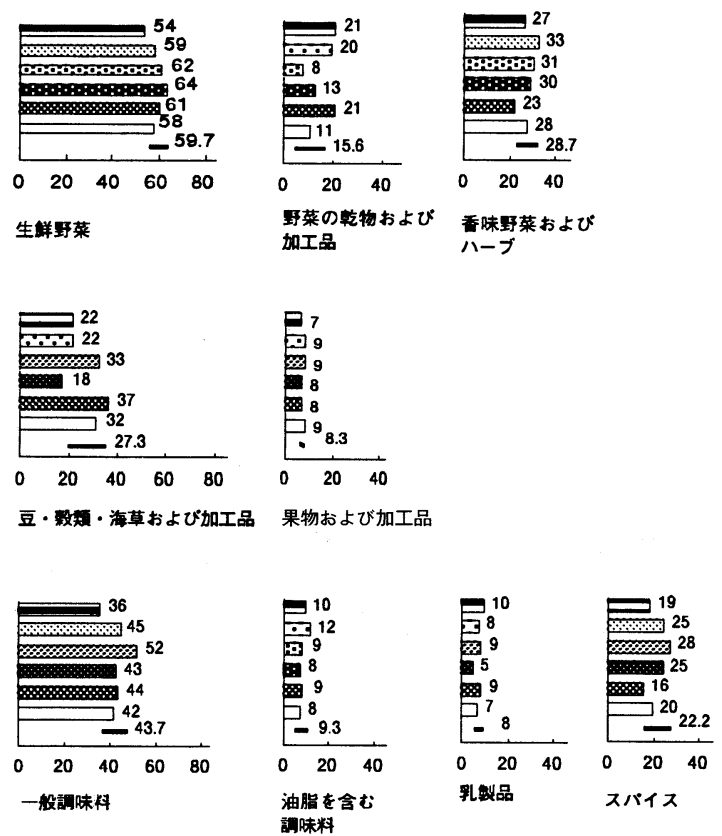

赔朋料
図 3 食材分類ごとの食材種類数 単位は種類数

各行とも左端は大分類を示す

魚介類および加工品, 獣鳥肉類および加工品は小分類を省く 
平均值として再構成した. 図 1 亿示すよ5に, 平均 8.2 切断や各種の調理操作を勘案すると, 食材数は直接的と 品で構成されていたが，平均食材数は図 2 亿示すよらに はい觉ないまでも, 食材調製の手間と係わってくる数值 1979年から1991年にむけて小さくなっていた．食生活に 扮いてはその運営上, 食材に施される洗浄 ${ }^{16)} \cdot$ 計量·

と考觉ることができる.したがって,料理構成食材数の減 少は, 洗ら手間や切る手間の少ない野菜・パックサラダの

大分類
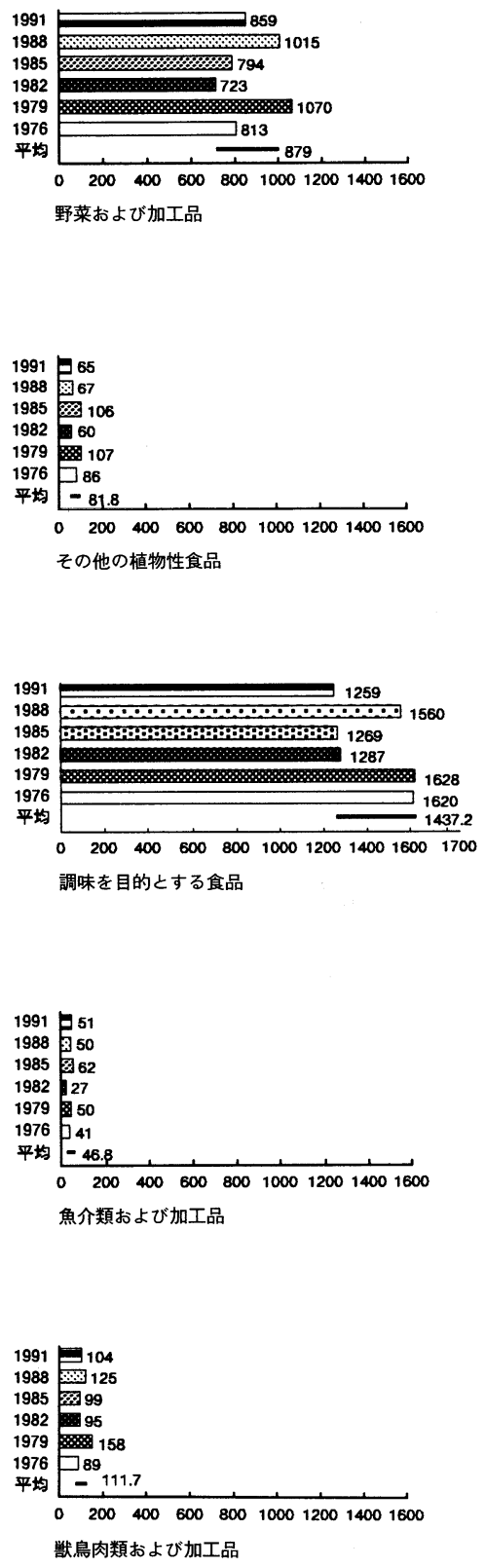

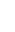

小分類
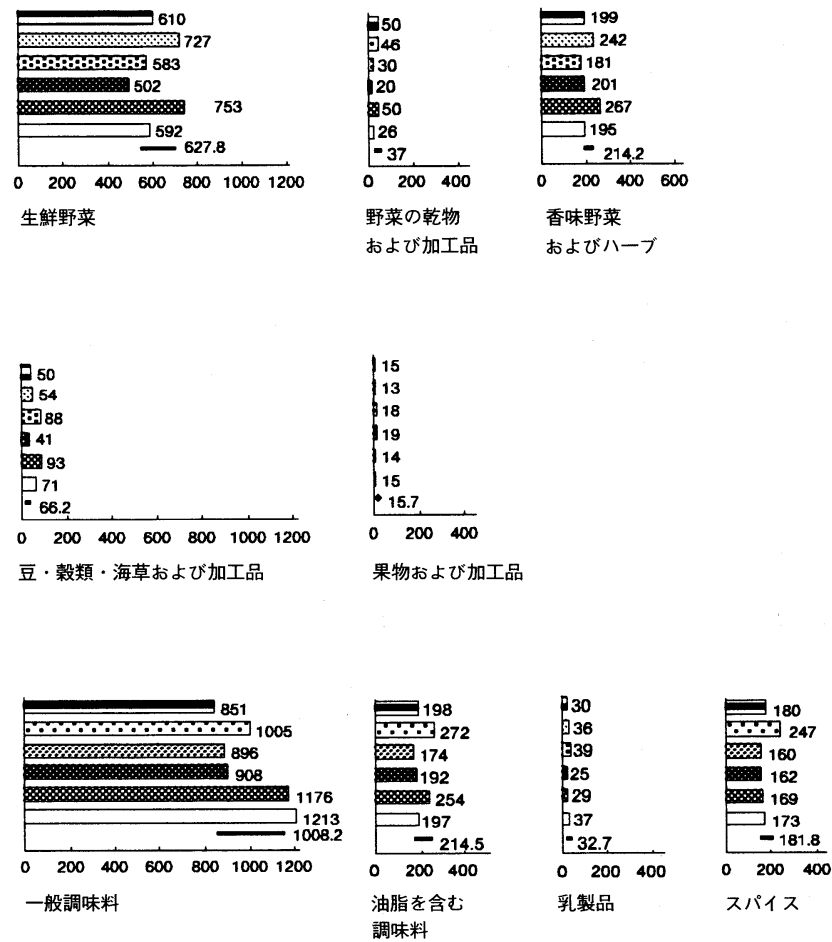

調味料
図4食材分類ごとの出現頻度 単位は度数 各行とも左端は大分類を示す 魚介類および加工品, 獣鳥肉類および加工品は小分類を省く 
普及など販売形態の変化といった背景に観察されるよう な, 調製の手間数の少なくなるよらな志向が料理情報の 上に，ある程度反映されたものと考劣る．次のその内容 について具体的に検討を行う.

\section{（2）食材の種類}

四 3 は左端に, 食材種類ごとの数を大分類に従って示 し，さらに下位分類の内訳を右に図示した.

野菜就よび加工品は野菜料理の主材料となる群である が, 最も種類数が多く, 年間平均 104 種類を示した.さ らにその内最も多かったのは生鮮野菜で, 平均 59.7 種類 であったが，80年代半ばをピークに漸減の傾向にある.

野菜の乾物および加工品は80年代半ばで減ったが，や や回復傾向にあった，また，市場で香辛つま物として扱 われ単価の高い少量消費野菜類は, ここでは香味野菜お よびハーブとして示したが, 平均 28.7 種類であった.

野菜および加工品以外の植物性食材では, 豆·穀類· 海草およびその加工品の種類が年により大きな変動を示 し, 果物扣よび加工品の種類は非常に少なかった. 野菜 と果物は販売の経路も栄養価のイメージも近いものがあ るが，フルーツサラダのような例を除き，野菜と組み合 わされて用いられることは少ない上らである.

動物性食材は, 魚介類 25.7 種類, 獣鳥肉類 33.2 種類で, いずれも年による変動が大きいことが特徵的であった. 魚介類・獣鳥肉類とも, 淡泊な味の野菜に濃厚な味をそ える材料として伝統的に各地域独特の組合せをみること ができるが，ここでの種類は野菜に比べると多いとはい 光ない。

調味を目的とする食材の種類は野菜に次いで多く, 総 種類は年平均 83.2 種類であり, 最も多くみられたのは 1985年であった.さらにその内訳をみると, 各種の調査 で調味料分類に括られる一般調味料が最も多く, 年平均 43.7 種類, ついでスパイスが 22.2 種類, 油脂を含を調味 料が9.3 種類, 乳製品は8.0 種類であった. 一般の調味料 に加え, 本報では, 味や風味を付与するための機能目的 で用いられたと考光られる少量使用の食材も調味食材と してこの分類に算入した. このため, 結果としてこの分 類に含まれるものが多くなったが，一般的な食品分類で はなく, 調理上の機能による食品の認識や分類は食生活 運営の視点から必要な側面であると考兄る.

\section{(3) 食材の出現頻度}

食材の出現頻度を度数として図 4 亿との分類ごとの内 訳を示した. 先の種類数と同様, 年によってかなり不規 則な変動を示しており,経年傾向は特にみられなかった。 そのらち最も出現頻度の大きかったのは調味を目的とす
る食材グループであった．野菜料理において主材料の野 菜種類が多いことは当然として, 調味を目的とする食材 が大きなウェイトをしめたことから, 野菜の含有水分の 高さに由来する呈味の弱さを補ら意味で, 調味食材の利 用頻度が高くなる構造の存在が推測できる.

以上, 出現した食材の種類や頻度数から観察して, 料 理構造に顕著な年次変化が観察されなかったことは, 観 測の16年間, 加工品を購入するのではなく, 食生活の運 営を日々行っている読者層が調製する, という視点から の野菜料理情報に, 直接大きな影響を及ぼす変化がなか ったと考觉る. 著者は, 類似の傾向として, 東京都中央 卸売市場年報の135品目中からモデルとして選んだ少量 消費野菜24品目の消費量が, 時系列分析により本報と重 なる16年間, 活とんど変化していない点を別報17) で検 出した。 したがって, 変化が大きいといわれる食生活の 中で, 野菜料理が変化している点を実証しょうとすれば, 同一名称であっても品種・産地・作型などの栽培形態, 流通形態の異なる野菜が周年性や利便性を獲得するため に出現しているといった生産や供給, 流通の変化を指す ことになるだろら。ささらには食物調製の外部化といら変 化が総務庁家計調查年報にみられる外食費や調理済食品 の購入の著しい増加から推測できるが, 野菜料理の詳細 は親くことができないので, 別の角度からの情報加工に より観察が必要となる。 また, 中尾 ${ }^{18)}$ は, ひとつの料 理の系の中で, 利用される食品種類や調理法には拡散の 時期と収束の時期がある, といら比較文化論的な立場か らの指摘を行っており，情報の観測スパンをさらに大き くとれば，野菜料理情報に関しても同様の認識が成立す るかもしれない。

\section{(4) 多様化の状況}

Forsterの式に基づいて計算を行った食材分類ごとの 多様化度を表 2 亿示した. 多様化度はその定義式からも 明らかなように, その系を構成する食材種類の多い状態 が必ずしも多様といらことにはならず, 種類と頻度数と が複合された状態で示される. 年次ごとの多様化度を全 食材の平均多様化度からみると, 1985年で最も高く 45. 83であった. 年次推移をみると, 多様化度が最高値を示 したのは野菜料理の主材料で, 野菜拉よび加工品は1991 年が 40.17 , そのうち生鮮野菜は1991年が 25.29 , 香味野 菜扔よびハーブは1988年が12.93, また野菜の乾物打よ び加工品は1988年に12.75であったが，他の分類項目も 含め年次の傾向は明膫には見られなかった．主材料であ る野菜の示した1980年代後半にみられるやや多様化度の 高い状況は, 背景に新野菜の開発や冷凍野菜の利用拡 
表 1 出現頻度上位 10 品目野菜と累積度

\begin{tabular}{|c|c|c|c|c|c|c|c|c|c|c|c|}
\hline \multicolumn{4}{|c|}{ 1976年 } & \multicolumn{4}{|c|}{ 1979年 } & \multicolumn{4}{|c|}{ 1982年 } \\
\hline & 度数 & $\begin{array}{l}\text { 相対 } \\
\text { 度数 }\end{array}$ & $\begin{array}{r}\text { 相対累積 } \\
\text { 度数 }\end{array}$ & & 度数 & $\begin{array}{l}\text { 相対 } \\
\text { 度数 }\end{array}$ & $\begin{array}{r}\text { 相対累積 } \\
\text { 度数 }\end{array}$ & & 度数 & $\begin{array}{l}\text { 相対 } \\
\text { 度数 }\end{array}$ & $\begin{array}{r}\text { 相対累積 } \\
\text { 度数 }\end{array}$ \\
\hline にんじん & 67 & 0.082 & 0.082 & にんじん & 94 & 0.088 & 0.088 & にんじん & 49 & 0.068 & 0.068 \\
\hline たまねぎ & 54 & 0.066 & 0.149 & たまねぎ & 64 & 0.060 & 0.148 & にんにく & 43 & 0.059 & 0.127 \\
\hline きゅうり & 47 & 0.058 & 0.207 & しょらが & 60 & 0.056 & 0.204 & たまねぎ & 42 & 0.058 & 0.185 \\
\hline しょらが & 34 & 0.042 & 0.248 & 根深ねぎ & 48 & 0.045 & 0.249 & なす & 39 & 0.054 & 0.239 \\
\hline じゃがいも & 30 & 0.037 & 0.285 & きゅうり & 46 & 0.043 & 0.292 & じゃがいも & 34 & 0.047 & 0.286 \\
\hline にんにく & 27 & 0.033 & 0.319 & じゃがいも & 45 & 0.042 & 0.334 & だいこん & 34 & 0.047 & 0.333 \\
\hline とらがらし & 27 & 0.033 & 0.352 & セロリ & 40 & 0.037 & 0.371 & しょらが & 31 & 0.043 & 0.376 \\
\hline キャベツ & 26 & 0.032 & 0.384 & にんにく & 38 & 0.036 & 0.407 & きゅうり & 26 & 0.036 & 0.412 \\
\hline だいこん & 24 & 0.030 & 0.413 & トマト & 34 & 0.032 & 0.438 & トマト & 23 & 0.032 & 0.444 \\
\hline なす & 24 & 0.030 & 0.443 & だいこん & 31 & 0.029 & 0.467 & 根深ねぎ & 22 & 0.030 & 0.474 \\
\hline \multicolumn{4}{|c|}{$\mathrm{n}=813$} & \multicolumn{4}{|c|}{$\mathrm{n}=1070$} & \multicolumn{4}{|c|}{$\mathrm{n}=723$} \\
\hline \multicolumn{4}{|c|}{ 1985年 } & \multicolumn{4}{|c|}{ 1988年 } & \multicolumn{4}{|c|}{ 1991年 } \\
\hline & 度数 & $\begin{array}{l}\text { 相対 } \\
\text { 度数 }\end{array}$ & $\begin{array}{r}\text { 相対累積 } \\
\text { 度数 }\end{array}$ & & 度数 & $\begin{array}{l}\text { 相対 } \\
\text { 度数 }\end{array}$ & $\begin{array}{r}\text { 相対累積 } \\
\text { 度数 }\end{array}$ & & 度数 & $\begin{array}{l}\text { 相対 } \\
\text { 度数 }\end{array}$ & $\begin{array}{r}\text { 相対累積 } \\
\text { 度数 }\end{array}$ \\
\hline にんじん & 74 & 0.093 & 0.093 & にんじん & 81 & 0.080 & 0.080 & にんじん & 57 & 0.066 & 0.066 \\
\hline たまねぎ & 50 & 0.063 & 0.156 & たまねぎ & 55 & 0.054 & 0.134 & たまねぎ & 46 & 0.054 & 0.120 \\
\hline じゃがいも & 37 & 0.047 & 0.203 & トマト & 46 & 0.045 & 0.179 & きゅうり & 39 & 0.045 & 0.165 \\
\hline しょらが & 34 & 0.043 & 0.246 & きゅうり & 45 & 0.044 & 0.224 & じゃがいも & 32 & 0.037 & 0.203 \\
\hline だいこん & 30 & 0.038 & 0.283 & にんにく & 41 & 0.040 & 0.264 & セロリ & 29 & 0.034 & 0.236 \\
\hline にんにく & 29 & 0.037 & 0.320 & キャベッ & 38 & 0.037 & 0.301 & トマト & 29 & 0.034 & 0.270 \\
\hline トマト & 28 & 0.035 & 0.355 & ピーマン & 33 & 0.033 & 0.334 & レモン & 28 & 0.033 & 0.303 \\
\hline きゅうり & 25 & 0.031 & 0.387 & じゃがいも & 33 & 0.033 & 0.367 & にんにく & 27 & 0.031 & 0.334 \\
\hline ピーマン & 22 & 0.028 & 0.414 & セロリ & 31 & 0.031 & 0.397 & 根深ねぎ & 27 & 0.031 & 0.366 \\
\hline 根深ねぎ & 21 & 0.026 & 0.441 & パセリ & 30 & 0.030 & 0.427 & とらがらし & 26 & 0.030 & 0.396 \\
\hline
\end{tabular}

表 2 各食材分類ごとの多様化度

\begin{tabular}{|c|c|c|c|c|c|c|c|c|}
\hline 採録年 & 1976 & 1979 & 1982 & 1985 & 1988 & 1991 & 平均 & 偏差 \\
\hline 全食材 & 33.00 & 40.42 & 38.31 & $45.83 *$ & 41.02 & 43.00 & 40.26 & 3.99 \\
\hline 野菜および加工品 & 33.05 & 32.57 & 33.47 & 33.43 & 36.91 & $40.17 *$ & 34.93 & 2.73 \\
\hline 生鮮野菜 & 21.72 & 20.69 & 21.8 & 22.02 & 22.76 & $25.29 *$ & 22.38 & 1.44 \\
\hline 香味野菜执よびハーブ & 10.25 & 9.64 & 10.09 & 10.37 & $12.93 *$ & 11.48 & 10.79 & 1.11 \\
\hline 野菜の乾物括よび加工品 & 4.70 & 7.06 & 6.25 & 3.38 & $12.75 *$ & 12.02 & 7.69 & 3.52 \\
\hline その他の植物性食材 & 26.2 & $26.69 *$ & 15.79 & 23.02 & 20.13 & 18.45 & 17.35 & 8.48 \\
\hline 豆·縠物・海草扰よび加工品 & 19.77 & $22.12 *$ & 10.57 & 18.09 & 14.73 & 13.89 & 16.53 & 3.87 \\
\hline 果物执よび加工品 & 6.43 & 5.15 & 5.23 & 5.40 & $6.76^{*}$ & 4.59 & 5.59 & 0.76 \\
\hline 調味を目的とする食材 & 13.70 & 14.39 & 15.07 & $16.40^{*}$ & 14.86 & 14.73 & 14.86 & 0.82 \\
\hline 一般調味料 & 8.55 & 9.02 & 9.25 & $9.17 *$ & 8.18 & 8.43 & 8.77 & 0.40 \\
\hline 油脂を含む調味料 & 3.15 & 3.16 & 2.96 & 3.03 & $3.98 *$ & 3.16 & 3.24 & 0.34 \\
\hline 乳製品 & 3.83 & $4.98 *$ & 3.14 & 3.67 & 2.58 & 4.79 & 3.83 & 0.85 \\
\hline スパイス & 4.08 & 2.65 & 3.45 & $5.03 *$ & 2.86 & 3.55 & 3.60 & 0.79 \\
\hline 魚貝類および加工品 & 17.69 & $23.15^{*}$ & 12.36 & 20.66 & 11.26 & 13.76 & 16.48 & 4.38 \\
\hline 獣鳥肉類および加工品 & 12.59 & 15.06 & $16.68 *$ & 12.74 & 12.37 & 14.94 & 14.06 & 1.60 \\
\hline
\end{tabular}

* 各分類項に括ける最大值 
大傾向によるものと推測する.

このように，多様化度の最も高かったのは主材料であ る野菜であり，野菜の相対的に多様な選択利用によって 野菜料理が機能していることが確認でさた．しかし，表 1 にも見られたよらに，累積度の上位品目に出現するに んじん・たまねぎ・きゅうり・じゃがいも・だいこん・ ねぎなどは，少なくともここ十数年間変化がない。この 結果は, 主要野菜28品目で野菜の作付け面積の約 $85 \%$ を 占めているといら生産実態や，各種調査結果19) 21) に みられる利用実態の上位品目に変化をみいだせない状況 ともほぼ一致している．食生活運営に拈いて，食材選択 の意思決定因子である価格の安定 ·周年性・手に入りや すさ・調理の際の使いやすさ・広範囲の調理への利用可 能性などが，自由に記述できるはずの料理情報にも反映 されているとみなせる。

調味を目的とする食材類は, 種類や度数の大きさにも かかわらず，多様化度が高くなかった。本報で, 調味を 目的とする食材の定義範囲を大きくとり, 種類・出現頻 度とも大きいものであったにもかかわらず多様化度が高 くなかったことは，上位品目の集中度がかなり大きいこ とと関連する．調味といら操作は，出現頻度上位にある しお・しょらゆ・さとら・さけ・酢・油・こしょらなど の基本調味料を組み合わせながら行われ，組み合わせの 種類や配合比率が料理の様式や個性といった質に関与す る.このような組み合わせに存在する多様な状態は今回 計測できなかったが，若い人々の一部に生じている調理 に打ける味付困難感22)，一般的な生活時間の不足にとも なら省力化の要求などが市販の合わせ調味料やサラダ ソース類の市場拡大などに繋がっているものと思われる ので，食材の市場における多様な状況は，別の角度から 検討を行いたい.

（5）多様化度と累積度数分布との関係

従来から汎用に用いられている累積度数分布は, 系内 の分布の状態を記述する指標となるが, 記述目的の似通 っている多様化度指数（D.I.）との関係の比較検討を 行った. 各分類項目，各年の多様化度指数に対し上位 5 位までの累積相対度数分布 (Cumlative Relative Freqency Distribution)の累積度（\%）を対数值でプロットす ると, 両者の間には, 図 5 のよらな直線性がみられ, か なり高い説明力を示す自由度調整済決定係数 $\overline{\mathrm{R}}_{2}=0.907$ を持つ回帰式が得られ, 係数の有意性が示された. した がって，多様化度は累積度数分布のような汎用な方法を 説明でき，また分類を構成する品目数や階級などにかか わりなく種類と度数を同時観測にかけられ，系の状態を
単純に計量的に表現できるという点で評価できる。しか し, 定義式から明らかなよらに, 系全体に占める部分 (フ ラクション）の大きさが系の多様化度を決定するといら 概念は明快であるが，ディメンションを持っていないの で，相対的にその数值の意味を探る必要があり，他の事 例への適用を重ねることにより検討してゆきたい。

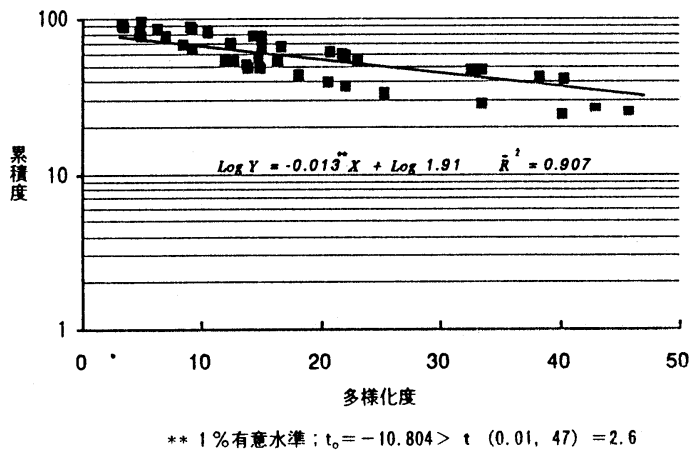

図 5 多様化度と累積度の関係

\section{4. 要 約}

最近16年間に発行された，食の専門誌から採録した野 菜料理を対象として，ビブリオメトリックス分析を行っ た. 野菜料理に選択された食材の種類，頻度数から選択 利用状況の多様性に関し検討を行った結果は，次のよう に要約される.

1）食材種類として最も多かったのは主材料である野 菜扣よび加工品であり，年間平均で104種類であっ た. 年次傾向はみられず，16年間の変化は大きく ないものと推定される.

2）食材出現頻度の最も高かったのは調味を目的とし て用いられた食材であり，野菜料理には調味料の ウエイトが高いことが確認できた．年次傾向はみ られず，16年間の変化は大きくはないものと推定 される。

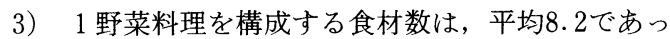
た。この値は，1979年から1991年に向けて少しず つ小さくなっていた.

4）多様化度は，1976年にやや低下したことを除き， 年次傾向はみられず，16年間の変化は大きくない ものと推定される。

5）野菜の選択利用に用いられる食材の多様化度と食 材の出現頻度の度数分布上位 5 品目の累積度の間 に高い相関がみられた。

以上本報の範囲内で結論すると，大量生産による既製 
品ではなく，家計内あるいはそれに準じる日常の状況で 作りあげるといら視点から記述された野菜料理情報から 分析する限り, 野菜料理に打いて選択される食材の質的 内容は，ここ16年間ほとんど変化していない. また，期 待の込められた内容であり,さらにはかなり自由に記述 できるはずの料理レシピも, 経済性, 食材の汎用性, 調 理の手間, 嗜好などの食生活運営に伴ら要因が意識され た情報を形成しており, 食生活運営上の制約が盛り込ま れている情報であることが確認されたものと考える.

したがって, 食生活が多様になっているといわれる一 般的評価は, 野菜を例にとれば市場に新野菜が出回る機 会が昔より絶対的には増加している状況や, 新しい栽培 品種の研究, 輸入作物の増加など, 供給実態に基づく評 価からであろらと考えられるが，本分析には反映されな かった. 本報のよらに家計内での利用を想定した情報に 関しては, 食材選択に際しての入手の方法や, 購入場所, 購入形態, あるいは外食に打ける新しい野菜23) の体験 などの他の情報を追加し，実証的に検討を加えることが 必要となると思われる。

本課題は, 平成元年度山崎香辛料財団研究助成の一部 であることを記し，同財団のご援助に謝意を表します. ご助言を賜りました東京農業大学武藤和夫教授に感謝申 し上げます。

本研究の概要は, 平成 5 年 9 月, 日本調理科学会平成 5 年度 大会に拀いて発表したことを付記します。

\section{参考文献および注}

1）厚生省保健医療局健康増進栄養課 : 平成 5 年版国民栄養 の現状，第一出版，pp. 38～39（1993）

2）総務庁統計局：家計調查年報平成 3 年，第16表（1992）

3）岡本順子, 加藤みゆき, 大森正司, 川端晶子, 佐々木敏 男 : データベースによる郷土料理の構造解析, 家政学雑誌, 第38巻， 5 号， pp. 425〜429（1987）

4) 下村道子, 高橋ユリア, 渡辺雄二, 吉松藤子 : 郷土理 · 行事食に拉ける汁物の分類, 調理科学, Vol.21, pp. 87 93 (1988)

5）茂木美智子, 深井康子, 赤羽ひろ, 川染節江, 品川弘子, 日比喜子 : 料理書にみられるすし構成要素の分析, 調理科 学, 21, pp. 268 273 (1988)

6）村山篤子, 三輪里子, 佐藤文代, 岩瀬靖彦, 君羅満 : 食 の専門誌の献立カレンダーからみた昭和 20 年〜 30 年代の食 生活の変化, 栄養学雑誌, Vol. 50, No. 6, pp. 337 345 (1992)
7) A. Pritchard : Statistical bibliography or bibliometrics, Journal of Documentation, Vol. 25, No.4, pp.348 349 (1969)

ビブリオメトリックス(Bibliometrics)は, 1969年プリチャー ド (A. Pritchard)によって提唱された用語で, 計量書誌学 ・計量文献学・計量情報学など様々に訳されており, 定訳 は未だない。「数学的手法の, 図書やその他伝達メディア への応用」,「記録された情報の伝達過程における計量化を 図る研究」などの解釈もある。科学者の情報活動, コミュ ニケーション過程, 行動パターンの利用にも可能であると 言われているので, 本課題に適用を試みた。料理情報は, 書かれた時点では，技術的な情報にすぎないが，集積し計 量的な処理にかけることによって, 食生活システムの部分 的情報となるものと考学る。

8）河井智康汪か：世界の多獲性浮魚資源の変動(2), 東海区 水産研究所業績 c 集, p. 43 (1982)

9）小山章夫 : 動物プランクトンの群集生態学的研究, 沿海 調査開発株式会社, p.10（1979）

10） E. C . ピールー, 南雲仁一監訳 : 数理生態学, 産業 図書, pp. 224 257 (1986)

11）鈴木継美昮：栄養摂取に括ける食材料構成の多様性, 栄養と食糧, 34, 3, p. 256（1981）

12）足立巳幸 : 都市の食生活研究, 食生活研究, p. 174, 第 一出版 (1975)

13) G. W. Forster:Farm Organization and Management, pp. 406 408, Prentice Hall (1953)

14）茂木美智子, 深井康子, 赤羽ひろ, 川染節江, 品川弘 子, 日比喜子 : 料理書にみられるすし構成要素の分析, 調 理科学, 第 21 巻, 第 4 号, pp. $268 \sim 273$ (1988)

15）茂木美智子: 料理の変遷に関する実証的研究, 東横学 園女子短期大学紀要, 第24号, pp. 38〜 51（1989）

16）今村恒一, 市川憲良, 松井昌幸, 茂木美智子, 紀谷文樹 : 調理実習室に扮ける使用水量の分析, 昭和 63 年度空気調 和·衛生工学会学術講演会講演論文集, pp. 93 96（1988）

17）茂木美智子：少量消費野菜の需要の傾向之調理特性か らみた特徵一『東京都中央卸売市場年報』による分析一， 家政学雑誌, 第 45 巻, No 9 , pp. 47〜 55 (1994)

18）中尾佐助：料理の起源, 日本放送出版協会, p. 39 (1973)

19）川端晶子：学校給食の献立構成要素の解析と料理素材 としての野菜, 日本施設園芸協会, 野菜消費基礎情報整理 推進事業, 野菜々健康委員会報告, pp. 44 45（1993）

20）加茂佑子; 京都市編：京都市内の青果物生産·加工 · 流通・消費に関する総合実態調査報告書, p. 86 (1984)

21) M. Moteki and H.G. Muller : Comparative study of vegetable intake in Japan and the United Kingdom, Journal of Consumer Studies and Home Economics, Vol. 16, pp. 317 $\sim 329$ (1992)

22）茂木美智子; 国民生活センタ一編 : 食と生活, p. 136, 光生館 (1984)

23）外食産業総合調査研究センター：外食向野菜の市場外 流通チャンネル, pp. 3 41, 外食産業総合調査研究センター (1990) 